\title{
Pengaruh Pemanasan dan Ethylen Glycol pada Elektrodeposisi Lapisan Tipis Magnetite menggunakan Continue Direct Current
}

\author{
Sylvina Tebriani* \\ Program Pascasarjana FMIPA Universitas Andalas \\ Kampus Limau Manis, Padang 25163 \\ Syukri \\ Departemen Kimia FMIPA Universitas Andalas \\ Kampus Limau Manis, Padang 25163 \\ Dahyunir Dahlan \\ Laboratorium Fisika Material, \\ Departemen Fisika FMIPA Universitas Andalas \\ Kampus Limau Manis, Padang 25163
}

Intisari

Telah berhasil dilakukan penumbuhan lapisan tipis magnetite $\left(\mathrm{Fe}_{3} \mathrm{O}_{4}\right)$ di atas substrat Indium Tin Oxide (ITO) dengan metode elektrodeposisi (ED), menggunakan Continue Direct Current (CDC). Karakterisasi XRD menunjukkan bahwa proses pemanasan sangat mempengaruhi terbentuknya lapisan tipis magnetite. Magnetite terdeposisi dengan struktur FCC dengan ukuran kristal 32,617 nm sampai 185,521 nm, dibawah kontrol konsentrasi surfaktan terhadap pelarutnya. Parameter deposisi optimum adalah ukuran kristal dan permukaan yang lebih halus. Parameter kisi masing-masing sampel adalah 8,313, 8,365, 8,354, 8,351, sedikit lebih rendah dari nilai standar 8.375 (JCPDS \# 01-088-0315). Sedangkan jarak antar bidang kristal yang diperoleh berada pada kisaran 2,507 sampai dengan 2,522. Hasil karakterisasi SEM menunjukkan bahwa magnetite tersebar merata di atas substrat ITO. Tiga sampel $(\mathrm{K}, \mathrm{O}, \mathrm{P})$ terdeposisi dalam bentuk agregat dari kristal magnetite. Sedangkan sampel Q terdeposisi dalam bentuk lapisan.

\begin{abstract}
Magnetite $\left(\mathrm{Fe}_{3} \mathrm{O}_{4}\right)$ film was successfully deposited on a ITO substrat by Electrodeposition (ED) technique use a Continue Direct Current (CDC). XRD characterization show that the heating process is very influences the formation of a thin layer of magnetite. Magnetite deposited with FCC structure with crystal size of $32.617 \mathrm{~nm}$ to $185.521 \mathrm{~nm}$, under the control of the surfactant concentration of the solvent. Deposition parameter optimum is refined crystal size and minimum surface roughness. Lattice parameter of each sample is $8.313,8.365,8.354$ , 8.351, slightly lower than the standard value 8375 (JCPDS \# 01-088-0315). While the spacing the crystal planes were obtained in the range of 2.507 to 2.522 . SEM characterization results showed that magnetite is spread evenly over the substrate Indium Tin Oxide (ITO). Three samples (A, C, D) deposited in the form of aggregates of magnetite crystals. While the $\mathrm{Q}$ sample deposited in the form of layer.
\end{abstract}

KATA KUNCI: magnetite, electrodeposition, Continue Direct Current (CDC), ethylene glycol.

\section{PENDAHULUAN}

Lapisan tipis merupakan bahan dalam jangkauan beberapa nanometer atau nanolayer yang dibentuk oleh susunan dan penggabungan sifat-sifat atom. Lapisan tipis dibuat dengan teknik penumbuhan atom atau partikel pada permukaan substrat dengan ketebalan sampai orde mikrometer. Sifat umum lapisan tipis dari suatu bahan berbeda dengan bahan padatan,

\footnotetext{
*E-MAIL: sylvina_tebriani@yahoo.com
}

hal ini disebabkan oleh perbedaan proses preparasinya, komposisi, morfologi dan strukturnya. Berbagai bahan yang memiliki potensi sebagai semikonduktor telah banyak diteliti, mulai dari bahan yang memiliki sifat fotokatalis, magnetic storage dan dielektrik. Lapisan tipis ferromagnetik oksida dapat digunakan sebagai bahan memori penyimpanan data yang terdiri atas bagian multilayer magnetik untuk menyimpan informasi [1].

Sifat-sifat lapisan tipis yang ditumbuhkan dapat dimodifikasi sesuai dengan tujuan penerapannya. Kemampuan suatu bahan untuk diaplikasikan tidak terlepas dari inovasi terhadap unsur penyusun utama lapisan tipis, salah satu con- 
tohnya adalah mineral magnetik. Istilah mineral magnetik biasanya digunakan untuk mineral-mineral yang tergolong ferromagnetik. Mineral magnetik biasanya berasal dari keluarga besi titanium oksida, sulfida besi dan hidroksi besi. Secara umum mineral magnetik dapat dikelompokkan menjadi magnetite $\left(\mathrm{Fe}_{3} \mathrm{O}_{4}\right)$, hematite $\left(\alpha \mathrm{Fe}_{2} \mathrm{O}_{3}\right)$, dan maghemite $(\gamma$ $\mathrm{Fe}_{2} \mathrm{O}_{3}$ ). Ketiga bentuk oksida besi ini sangat berguna dalam teknologi.

Magnetite merupakan mineral magnetik yang terkuat dengan komposisi kimia $\mathrm{Fe}_{3} \mathrm{O}_{4}$, dan magnetisasi $90 \mathrm{Am}^{2} / \mathrm{kg}$ sampai dengan $93 \mathrm{Am}^{2} / \mathrm{kg}$ [2]. Magnetite dapat dimanfaatkan dalam berbagai aspek seperti perekat tinta magnetik, media perekam magnetik dan katalis. Pemanfaatan magnetite semakin meluas dengan dikembangkannya magnetite dalam dimensi nanometer [3-5]. Daya tarik material magnetite terletak pada sifat-sifat uniknya yaitu sifat kemagnetannya yang berbeda dengan material ukuran bulk, serta luas reaktivitas permukaannnya yang besar. Magnetite dalam dimensi nano bersifat superparamagnetik dan dapat dimanipulasi oleh suatu medan eksternal tertentu [6]. Respon yang kuat terhadap medan magnet luar menjadikan magnetite sangat berguna untuk kepentingan riset dan dalam dunia industri yang berbasis kemagnetan, misalnya dalam hal rekayasa elektronika, pembuatan magnet permanen, industri baja, sampai untuk pembuatan lapisan tipis [7]. Magnetite bagai bahan ferromagnetik oksida dapat digunakan sebagai bahan penyimpan data sebagai bagian multilayer magnetik untuk menyimpan informasi [1], untuk itu maka perlu dilakukan kajian lebih lanjut tentang sifat fisis bahan magnetite yang dibuat dalam bentuk lapisan tipis. Terdapat sejumlah teknik deposisi untuk penumbuhan film tipis magnetite, beberapa diantaranya Chemical Vapor Deposition (CVD), Physical Vapor Deposition (PVD), elektrodeposisi, spraying, dan spin coating. Setiap metoda ini memiliki hasil pelapisan yang berbeda tergantung pada proses penumbuhannya.

Pada penelitian ini metode yang digunakan untuk membuat lapisan tipis magnetite adalah secara elektrodeposisi karena lebih mudah dilakukan. Metode elektrodeposisi adalah teknik yang paling sederhana dan ekonomis. Oleh karena itu metoda ini menjadi motivasi kerja bagi peneliti untuk menyelidiki penumbuhan film tipis magnetite melalui metoda elektrodeposisi. Proses elektrodeposisi dapat dilakukan dengan menerapkan arus searah (CDC) dan arus pulsa (PDC).

Pada penelitian ini elektrodeposisi ini dilakukan dalam sel yang terdiri dari larutan yang mengandung $\mathrm{Fe}_{2}\left(\mathrm{SO}_{4}\right)_{3}$ yang diencerkan dengan alkohol 97\%. Proses dilakukan dengan menggunakan arus searah (CDC) dengan variasi penambahan surfaktan. Surfaktan yang digunakan adalah ethylen glycol, karena bersifat adhesif dengan daya rekat tinggi terhadap substrat serta pada katoda digunakan kaca yang dilapisi ITO yang bersifat konduktif.

\section{METODOLOGI}

Kaca ITO yang akan digunakan sebagai substrat dipotong dengan ukuran $2,5 \mathrm{~cm} \times 0,5 \mathrm{~cm}$ Setelah pemotongan dilakukan, sisi bekas pemotongan diperhalus dengan menggu- nakan amplas halus. Substrat kaca ITO dibersihkan dengan menggunakan aquades dan kemudian dibilas dengan alkohol untuk menghilangkan kotoran yang masih menempel pada ITO.

Pembuatan larutan diawali dengan larutan $\mathrm{Fe}_{2}\left(\mathrm{SO}_{4}\right)_{3}$ dengan konsentrasi 0,1 M. Pembuatan larutan dilakukan dengan cara menimbang sejumlah massa $\mathrm{Fe}_{2}\left(\mathrm{SO}_{4}\right)_{3}$, dan penambahan alkohol sampai volume yang diinginkan. Kemudian larutan tersebut diaduk di dalam gelas beacker menggunakan magnetic stirer kurang lebih selama 4 jam. Tujuan dari pengadukan ini agar semua bahan yang dicampurkan dapat menjadi campuran yang homogen dan tidak mengendap.

Sejumlah volume $\mathrm{C}_{2} \mathrm{H}_{6} \mathrm{O}_{2}$ ditentukan, untuk menghasilkan surfaktan dengan $\%$ volume $0,1,0,02$, dan 0,01 terhadap pelarutnya. Pembuatan larutan dilakukan dengan cara mengambil sejumlah volume $\mathrm{C}_{2} \mathrm{H}_{6} \mathrm{O}_{2}$ dan diencerkan dengan alkohol dalam labu ukur, kemudian larutan tersebut diaduk di dalam gelas beacker menggunakan magnetic stirer selama 1 jam.

Pada katoda digunakan ITO dan pada anoda digunakan platinum $(\mathrm{Pt})$. Pada tahap awal, akan dilakukan proses elektrodeposisi dengan konsentrasi $0,1 \mathrm{M}$ dengan tegangan eksternal 3,5 volt, tanpa penambahan surfaktan. Deposisi dilakukan selama 2 jam.

Tahap selanjutnya adalah melakukan proses elektrodeposisi dengan konsentrasi $0,1 \mathrm{M}$ dengan tegangan eksternal 3,5 volt selama 2 jam, dengan penambahan surfaktan ethylen glycol sebanyak 5 tetes. Proses elektrodeposisi dilakukan dengan variasi $\%$ volume surfaktan $1 \%, 2 \%$, dan $10 \%$ terhadap pelarutnya. Deposisi juga dilakukan selama 2 jam. Sampel hasil deposisi dikeringkan, dipotong dan di panaskan pada suhu $400^{\circ} \mathrm{C}$ selama $1 \mathrm{jam}$.

\section{HASIL DAN DISKUSI}

\section{A. Hasil Karakterisasi XRD}

Terdapat lima sampel hasil elektrodeposisi yang akan dikarakterisasi dengan XRD, yaitu dua sampel hasil elektrodeposisi tanpa surfaktan (A.1 dan A.2). Perbedaan kedua sampel terletak pada proses pemanasan untuk mengetahui bagaimana pengaruh pemanasan terhadap hasil elektrodeposisi. Sampel A.1 adalah sampel yang dikarakterisasi tanpa dilakukan pemanasan terlebih dahulu, sedangkan sampel A.2 adalah sampel yang telah dipanaskan pada suhu $400^{\circ} \mathrm{C}$. Tiga sampel berikutnya adalah hasil elektrodeposisi dengan variasi konsentrasi penambahan surfaktan. Sampel B adalah sampel hasil elektrodeposisi dengan penambahan lima tetes surfaktan $1 \%$, sedangkan sampel C dengan penambahan lima tetes surfaktan $2 \%$, dan sampel D dengan penambahan lima tetes surfaktan $10 \%$. Hasil karakterisasi XRD, diperlihatkan masingmasing sampel oleh Gambar 1.

Ukuran rata-rata kristal dapat dihitung dengan menentukan dari hasil XRD menggunakan metode Scherrer dengan per- 


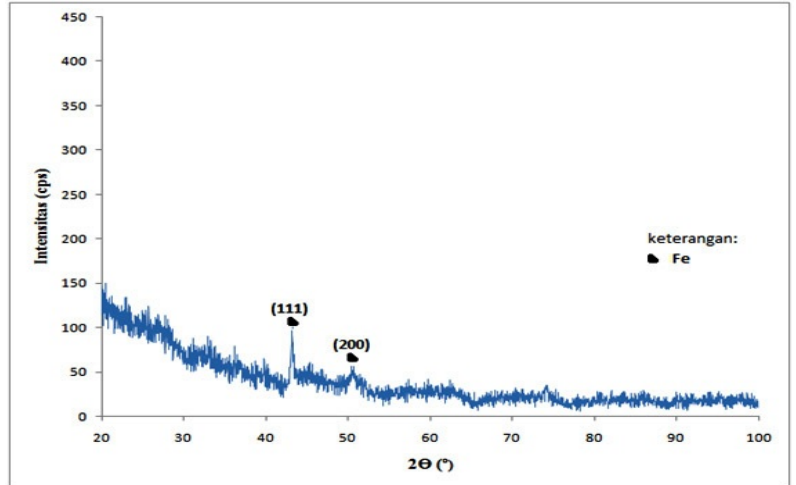

(a) Sampel A.1

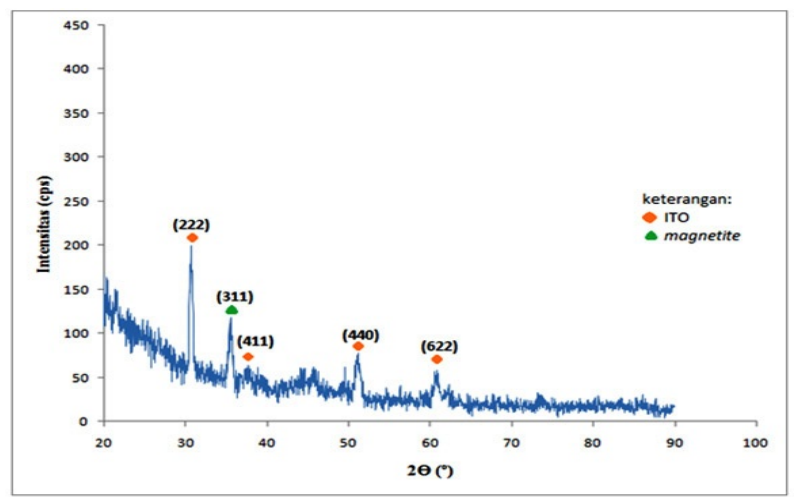

(c) Sampel B

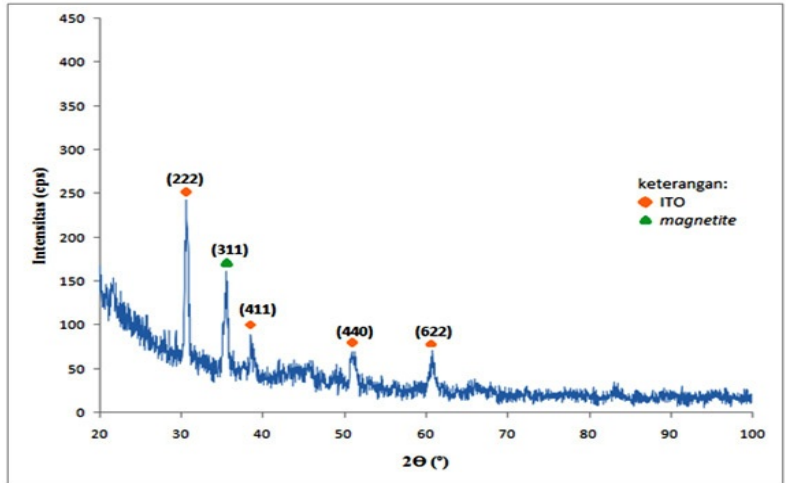

(b) Sampel A.2

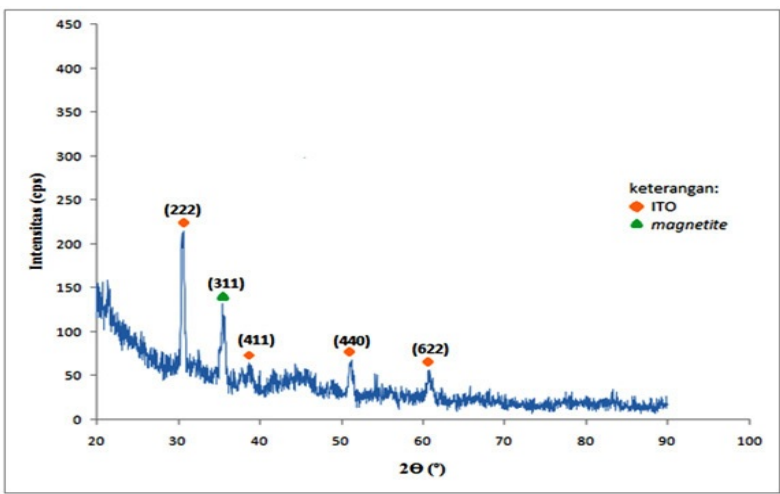

(d) Sampel C

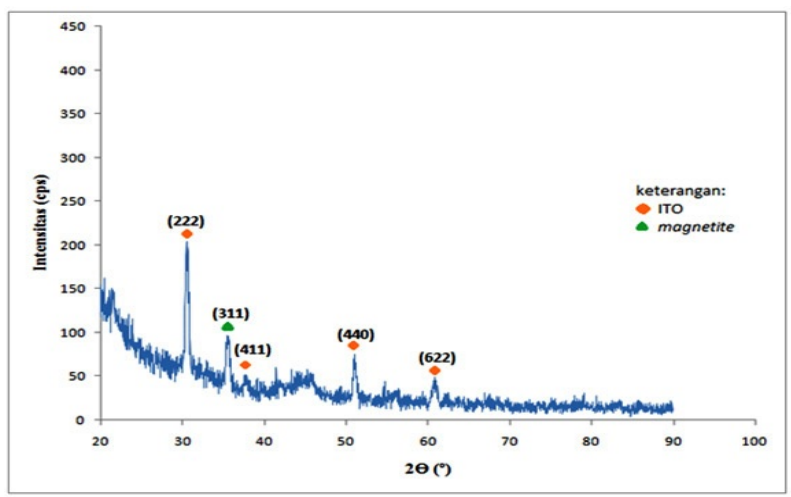

(e) Sampel D

Gambar 1: Pola difraksi XRD

samaan sebagai berikut:[8]

$$
\begin{gathered}
B=\frac{1}{2} \mathrm{FWHM} \\
D=\frac{k \lambda}{\beta \cos \theta}
\end{gathered}
$$

dengan $\mathrm{D}=$ ukuran kristal rata-rata, $(\mathrm{nm}) ; \mathrm{k}=$ konstanta material $(0,9) ; \lambda=$ panjang gelombang radiasi sinar-X, $(\mathrm{nm}) ; \theta$ = sudut Bragg (rad); $\beta=$ lebar puncak rata-rata yang didekati dengan lebar puncak pada setengah tinggi maksimumnya atau disebut dengan FWHM (Full Width at Half Maximum), satuan radian (rad).

\section{Sampel A.1}

Proses elektrodeposisi berlangsung pada tegangan 3,5 Volt dengan konsentrasi larutan elektrolit $\mathrm{Fe}_{2}\left(\mathrm{SO}_{4}\right)_{3}$ sebesar 0,1 $\mathrm{M}$, tanpa penambahan surfaktan ethylene glycol. Proses elektrodeposisi dilakukan pada suhu ruang selama 2 jam. Hasil elektrodeposisi dikarakterisasi dan menghadirkan pola difraksi seperti Gambar 1(a).

Gambar 1(a) menunjukkan pola difraksi dari sampel A sebelum di furnace (A.1). Pada tahap ini terlihat bahwa hasil deposisi yang terbentuk adalah 2 puncak Fe (besi) pada sudut $43,303^{\circ}$ dan $50,322^{\circ}$, dengan FWHM 0,307 dan 0,921. Berdasarkan identifikasi menggunakan JCPDS, maka diketahui indeks millernya yaitu (111) dan (220). Parameter kisi 
diperkirakan dari pola difraksi adalah $0,3614-0,3622 \mathrm{~nm}$, sedikit lebih tinggi dari nilai standar 0,3610 nm (JCPDS \# 01071-4649).

Pola difraktogram yang diperoleh juga dapat digunakan untuk menentukan ukuran kristal berdasarkan nilai FWHM pada berbagai puncak dengan menggunakan persamaan Scherrer (Pers.2). Dengan menggunakan persamaan Scherrer pada indeks bidang miller (111), ukuran kristal yang terhitung yaitu $55,704 \mathrm{~nm}$, sedangkan pada indeks miller (220) diperoleh ukuran kristal sebesar 19,007 nm. Hasil karakterisasi ini menunjukkan, pada keadaan ini belum terbentuk magnetite seperti yang diharapkan.

\section{Sampel A.2}

Sampel A.2 adalah sampel hasil elektrodeposisi pada tegangan 3,5 Volt dengan menggunakan larutan elektrolit $\mathrm{Fe}_{2}\left(\mathrm{SO}_{4}\right)_{3}$ tanpa surfaktan. Proses berlangsung selama 120 menit. Hasil elektrodeposisi dipanaskan pada suhu $400^{\circ} \mathrm{C}$ selama 60 menit. Merujuk pada hasil karakterisasi Sampel A.1, hasil karakterisasi dari sampel A.1 belum menghasilkan magnetite. Sehingga perlu dilakukan pemanasan pada sampel agar kristal Fe yang terbentuk dapat diikat oleh oksigen, sehingga terbentuk oksida besi. Pemanasan dilakukan pada suhu $400^{\circ} \mathrm{C}$, dengan waktu tahan 1 jam. Setelah dipanaskan, sampel kembali di karakterisasi dan menghasilkan pola difraksi seperti Gambar 1(b).

Hasil pola difraksi pada Gambar 1(b) menunjukkan bahwa, pada sampel A dengan penerapan tegangan eksternal sebesar 3,5 volt, pemanasan sampai $400^{\circ} \mathrm{C}$ dengan waktu tahan 60 menit, hasil deposisi yang terbentuk adalah 1 puncak $\mathrm{Fe}_{3} \mathrm{O}_{4}$ (magnetite) pada sudut $35,778^{\circ}$, dengan FWHM 0,090. Terdapat 4 puncak ITO pada sudut $30,863^{\circ}, 38,543^{\circ}, 51,446^{\circ}$ dan $60,785^{\circ}$. Pada tabel JCPDS dapat dilihat FWHM tiga puncak sama pada 0,090 dan 1 puncak pada 0,409. Dari hasil tersebut diidentifikasi dengan JCPDS maka untuk tiap puncak dapat diketahui indeks millernya yaitu magnetite (311) dan ITO (222), (440), (441), dan (622).

Parameter kisi diperkirakan dari pola difraksi adalah a = $0,8312 \mathrm{~nm}$, sedikit lebih rendah dari nilai standar $0,8375 \mathrm{~nm}$ (JCPDS \# 01-088-0315). Menggunakan persamaan Scherrer pada indeks bidang miller (311), magnetite hasil deposisi mempunyai ukuran kristal rata-rata (D) $185,521 \mathrm{~nm}$ dengan jarak antar kristal (d) 0,2506 nm.

\section{Sampel B}

Sampel B merupakan hasil elektrodeposisi dengan menggunakan tegangan eksternal sebesar 3,5 Volt dan 0,1 M larutan elektrolit $\mathrm{Fe}_{2}\left(\mathrm{SO}_{4}\right)_{3}$. Pada larutan elektrolit ditambahkan 5 tetes surfaktan dengan konsentrasi $1 \%$ terhadap pelarutnya. Sampel yang telah dikeringkan di furnace pada suhu $400^{\circ} \mathrm{C}$ selama 60 menit. Proses elektrodeposisi berlangsung dalam waktu 120 menit.

Pola difraksi Gambar 1(c) menunjukkan bahwa hasil deposisi yang terbentuk adalah 1 puncak $\mathrm{Fe}_{3} \mathrm{O}_{4}$ (magnetite) pada sudut $35,608^{\circ}$ dengan FWHM 0,511. Hasil identifikasi dengan JCPDS dapat diketahui indeks millernya yaitu (311), selain itu terdapat 4 puncak ITO pada sudut $30,606^{\circ}, 38,925^{\circ}$, $51,031^{\circ}$ dan $60,796^{\circ}$. Nilai FWHM dari keempat puncak yaitu 0,$461 ; 0,716 ; 0,819$ dengan indeks miller ITO yaitu (222), (440), (441), dan (622).

Parameter kisi magnetite diperkirakan dari pola difraksi adalah $\mathrm{a}=0,8351 \mathrm{~nm}$, sedikit lebih rendah dari nilai standar 0,8375 nm (JCPDS \# 01-088-0315). Menggunakan persamaan Scherer diperoleh bahwa magnetite hasil deposisi mempunyai ukuran kristal rata-rata (D) $32,617 \mathrm{~nm}$, dengan jarak antar kristal (d) 0,2518 nm. Jika dibandingkan dengan sampel A sampel B mempunyai ukuran kristal yang lebih halus dari pada sampel A.2, hal ini menunjukkan bahwa keberadaan surfaktan sangat mempengaruhi ukuran kristal yang dihasilkan. Kehadiran surfaktan membuat ukuran kristal magnetite yang didapatkan lebih halus.

\section{Sampel C}

Sampel C merupakan sampel hasil elektrodeposisi selama 120 menit, dengan larutan elektrolit $0,1 \mathrm{M}$ $\mathrm{Fe}_{2}\left(\mathrm{SO}_{4}\right)_{3}$, ditambahkan dengan 5 tetes larutan elektrolit ethylene glycol dengan volume $2 \%$ terhadap pelarutnya. Tegangan eksternal yang diberikan adalah 3,5 Volt. Sampel dipanaskan pada suhu $400^{\circ} \mathrm{C}$ dengan waktu tahan 60 menit.

Grafik polarisasi XRD (Gambar 1(d)) menampilkan hasil deposisi pada sampel $\mathrm{C}$, dimana terdapat puncak $\mathrm{Fe}_{3} \mathrm{O}_{4}$ (magnetite) pada sudut $35,595^{\circ}$ dengan FWHM 0,512, dan indeks miller (311). Selain itu juga terbaca 4 puncak ITO pada sudut, $30,463^{\circ}, 38,882^{\circ} 51,095^{\circ}$ dan $60,8467^{\circ}$. Pada tabel dapat dilihat FWHM ketiga puncak yaitu 0,205; 0,614; 0,512 dan 0,819, dengan indeks miller masing-masing (222), (411), (440) dan (622).

Parameter kisi magnetite diperkirakan dari pola difraksi adalah $\mathrm{a}=0,8355 \mathrm{~nm}$, sedikit lebih rendah dari nilai standar 0,8375 nm (JCPDS \# 01-088-0315). Ukuran magnetite hasil deposisi mempunyai ukuran kristal rata-rata (D) 32,617 $\mathrm{nm}$, dengan jarak antar kristal (d) 0,2519 nm. Jika dibandingkan dengan sampel $\mathrm{B}$, sampel $\mathrm{C}$ dengan konsentrasi surfaktan ethylene glycol $50 \%$ lebih pekat mempunyai ukuran kristal yang sama dengan dengan sampel B.

\section{Sampel D}

Sampel D dilakukan dengan menambahkan 5 tetes surfaktan dengan perbandingan volume $10 \%$ terhadap pelarutnya. Konsentrasi surfaktan pada sampel D 10 kali lebih pekat daripada sampel B, dan 2 kali lebih pekat daripada sampel C. Tegangan dan waktu elektrodeposisi adalah 3,5 volt dan 120 menit. Sampel di furnace selama 60 menit, dalam suhu $400^{\circ} \mathrm{C}$. Pola hasil karakterisasi X-Ray, ditunjukkan oleh Gambar 1(e).

Pola difraksi yang dihasilkan pada Gambar 1(e) menunjukkan bahwa hasil deposisi yang terbentuk adalah 1 puncak $\mathrm{Fe}_{3} \mathrm{O}_{4}$ (magnetite) pada sudut 35,555 dengan FWHM 0,409. Jika diidentifikasi dengan JCPDS maka untuk nilai puncak magnetite mempunyai indeks miller (311). Puncak lain yang teridentifikasi yatu 4 puncak ITO pada sudut $30,717^{\circ}$, $37,772^{\circ}, 51,033^{\circ}$ dan $60,835^{\circ}$ dengan FWHM 0,460; 0,614; 


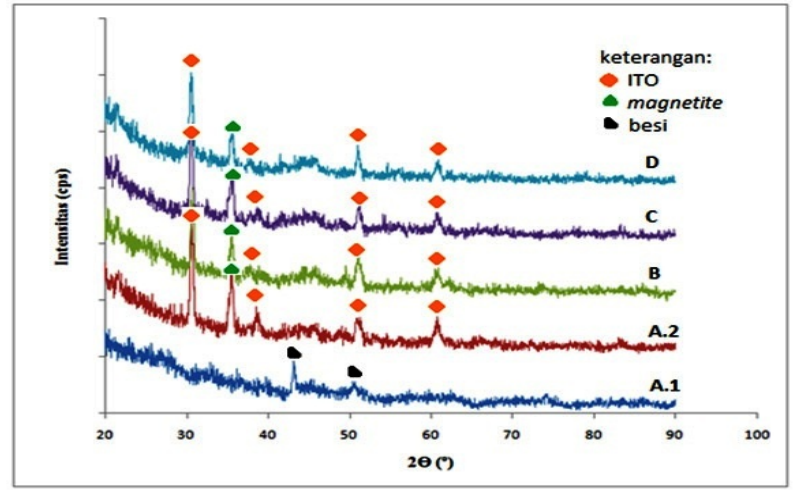

Gambar 2: Perbandingan Hasil Pola Difraksi XRD seluruh sampel

0,512; 0,090, dan 0,614 dan indeks millernya yaitu ITO (222), (440) dan (622).

Setelah dilakukan perhitungan terhadap nilai parameter kisi magnetite dari pola difraksi, nilainya yang didapatkan adalah $\mathrm{a}=0,8365 \mathrm{~nm}$, sedikit lebih rendah dari nilai standar 0,8375 nm (JCPDS \# 01-088-0315). Ukuran magnetite hasil deposisi mempunyai ukuran kristal rata-rata (D) 40,768 nm dengan jarak antar kristal (d) 0,2522109 nm. Jika dibandingkan dengan sampel B dan C, sampel D mempunyai ukuran kristal yang lebih kasar. Terlalu pekatnya konsentrasi surfaktan akan memperbesar ukuran kristal hasil elektrodeposisi.

\section{Plot Grafik Pola XRD secara Umum}

Jika diplot kurva hubungan antara intensitas terhadap sudut $2 \theta$ dari seluruh sampel maka di dapatkan pola difraksi gabungan seperti pada Gambar 2. Hasil karakterisasi XRD menunjukkan bahwa tanpa pemanasan hasil deposisi yang diperoleh masih dalam bentuk Fe (besi). Sedangkan untuk semua sampel yang telah dipanaskan diperoleh endapan magnetite fcc murni. Terlihat dari pola XRD yang dihasilkan, masingmasing sampel yang telah di furnace menunjukan pola yang hampir sama.

Parameter kisi magnetite diperkirakan dari pola difraksi sampel A, B, C, dan D berturut-turut adalah adalah a = 0,8313 $\mathrm{nm}, 0,8365 \mathrm{~nm}, 0,8354 \mathrm{~nm}$ dan $0,8351 \mathrm{~nm}$, sedikit lebih rendah dari nilai standar 0,8375 nm (JCPDS \# 01-088-0315). Hal ini menunjukkan bahwa penambahan surfaktan akan mempengaruhi nilai parameter kisi yang dihasilkan, semakin tinggi konsentrasi surfaktan semakin tinggi parameter kisi yang didapatkan.

Ukuran kristal magnetite masing-masing sampel adalah $185,521 \mathrm{~nm}, 40,768 \mathrm{~nm}, 32,617 \mathrm{~nm}$, dan 32,617 nm, dengan jarak antar bidang kristal masing-masing 0,2507 nm, 0,2522 $\mathrm{nm}, 0,2519 \mathrm{~nm}$ dan $0,2518 \mathrm{~nm}$. Nilai-nilai diatas menimbulkan asumsi bahwa surfaktan berperan sebagai pengontrol ukuran kristal dan jarak antar bidang kristal magnetite. Kondisi tanpa surfaktan membuat ukuran kristal dan jarak antar bidang kristal yang didapatkan lebih besar dari pada sampel dengan penambahan surfaktan ethylene glycol. Konsentrasi surfaktan yang terlalu pekat membuat ukuran kristal semakin besar. Jadi, untuk mendapatkan magnetite dengan uku- ran kristal yang lebih kecil, perlu diperhatikan perbandingan konsentrasi surfaktan ethylene glycol terhadap pelarutnya.

\section{B. Hasil Karakterisasi SEM}

\section{Morfologi Permukaan Hasil Elektrodeposisi}

Gambar 3(a) menunjukkan hasil elektrodeposisi sampel tanpa penambahan surfaktan. Dari gambar terlihat bahwa permukaan lapisan tipis terdeposisi oleh agregat atau cluster dari kristal-kristal magnetite yang tersebar secara merata, ukurannya berkisar antara 73,08 nm sampai $380,77 \mathrm{~nm}$. Hasil foto SEM memperlihatkan bahwa hasil deposisi didominasi oleh agregat dengan ukuran yang lebih besar yaitu sekitar 380,77 $\mathrm{nm}$, hal ini disebabkan karena pada larutan elektrolit tidak ditambahkan surfaktan ethylene glycol, sehingga menjadikan agregat yang terdeposisi berukuran lebih besar. Terlihat jelas bahwa keberadaan surfaktan ethylene glycol sangat mempengaruhi ukuran agregat yang akan terdeposisi.

Pada Gambar 3(b), merupakan hasil elektrodeposisi menggunakan larutan elektrolit dengan penambahan surfaktan dengan konsentrasi $1 \%$ terhadap pelarutnya. magnetite terdeposisi merata dalam bentuk lapisan, tetapi masih terdapat crack (retakkan). Hal ini kemungkinan disebabkan oleh suhu pemanasan yang terlalu tinggi yaitu $400^{\circ} \mathrm{C}$ dan waktu tahan yang terlalu lama. Gambar 3(c) menunjukkan bahwa permukaan lapisan tipis terdeposisi oleh agregat atau cluster dari kristalkristal magnetite berbentuk bola seragam yang tersebar secara merata, ukuran partikel berkisar antara 84,62 nm sampai $142,31 \mathrm{~nm}$. Kondisi larutan elektrolit dengan penambahan surfaktan dengan $2 \%$ terhadap pelarutnya menjadikan agregat atau cluster dari kristal-kristal magnetite yang terdeposisi berukuran lebih halus dari pada sampel D.

Gambar 3(d) menunjukkan bahwa permukaan lapisan tipis terdeposisi oleh agregat atau cluster dari kristal-kristal magnetite berbentuk bola seragam yang tersebar secara merata, ukuran agregat atau cluster berkisar antara 61,54 nm sampai $130,77 \mathrm{~nm}$. Kondisi larutan elektrolit dengan penambahan surfaktan dengan konsentrasi $10 \%$ terhadap pelarutnya menjadikan agregat magnetite yang terdeposisi berukuran lebih halus dari pada sampel A.2. Terlihat jelas bahwa keberadaan surfaktan sangat mempengaruhi ukuran agregat atau cluster dari kristal-kristal magnetite yang akan terdeposisi.

Setelah dilakukan perbesaran 40.000 kali terhadap sampel $\mathrm{B}$, terlihat lapisan magnetite yang terdeposisi membentuk patahan-patahan. Hal ini terjadi karena pada saat pembakaran pada suhu $400^{\circ} \mathrm{C}$ selama 1 jam tersebut ethylene glycol yang juga berfungsi sebagai perekat substrat dengan magnetite sudah menipis karena menguap lebih cepat pada substrat tersebut. Untuk itu agar lapisan yang terbentuk tidak retak, suhu pembakaran dan lamanya waktu tahan perlu diturunkan.

Morfologi permukaan hasil deposisi pada sampel tanpa penambahan surfaktan ethylene glycol lebih kasar dibandingkan dengan sampel yang diberi surfaktan ethylene glycol. Perbandingan konsentrasi surfaktan ethylene glycol terhadap pelarutnya juga ikut mempengaruhi morfologi. Sampel yang 


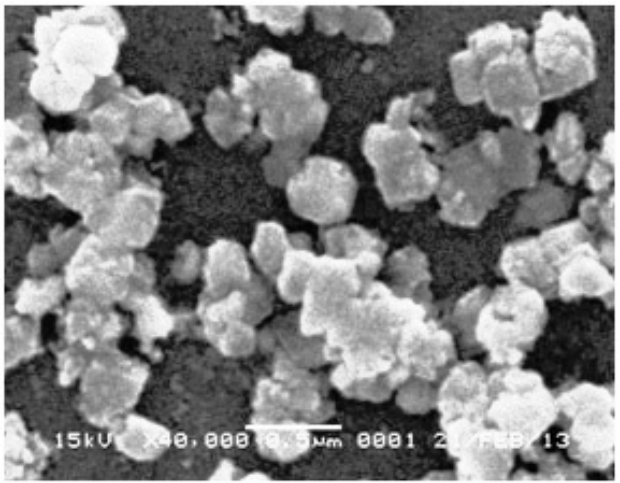

(a) Sampel A

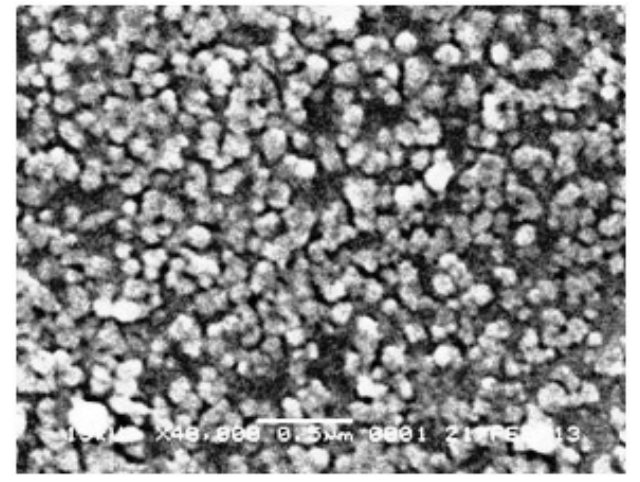

(c) Sampel C

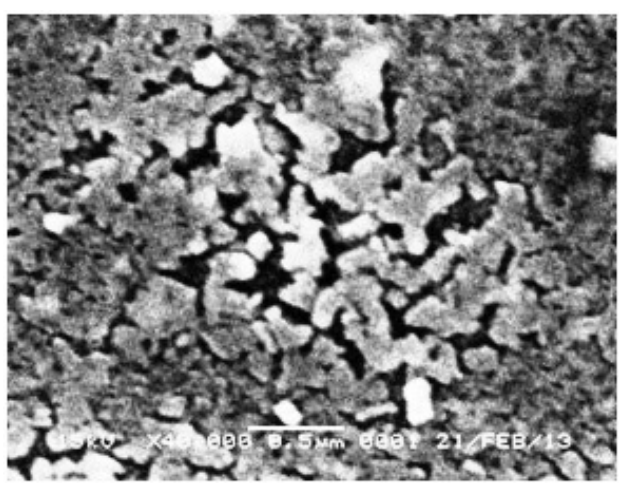

(b) Sampel B

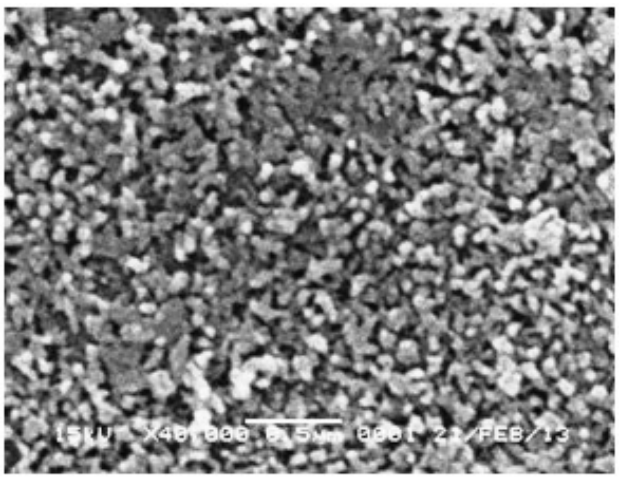

(d) Sampel D

Gambar 3: Hasil foto SEM

paling optimum untuk membentuk lapisan adalah pada konsentrasi rendah. Pekatnya surfaktan ethylene glycol menghasilkan deposisi dalam bentuk agregat atau cluster berbentuk butiran bola dari kristal-kristal magnetite. Hal ini bisa jadi disebabkan karena penambahan surfaktan ethylene glycol memperkecil ukuran kristal magnetite, sehingga lebih proses deposisi ke substrat berlangsung lebih cepat, dan agregat yang terbentuk semakin banyak.

\section{Foto SEM Tampang Melintang}

Pengukuran ketebalan lapisan tipis pada sampel C dan D dapat dilakukan dengan menggunakan foto hasil SEM tampang melintang. Setelah perhitungan dilakukan didapatkan hasil bahwa sampel D mempunyai ketebalan sekitar 268,041 nm sedangkan sampel C ketebalannya sekitar 360,825 nm. Terlihat pada Gambar 4 bahwa konsentrasi surfaktan terhadap pelarutnya ikut mempengaruhi ketebalan dan morfologi lapisan tipis yang dihasilkan. Semakin besar konsentrasi surfakan morfologi permukaan yang dihasilkan semakin halus dan merata.

\section{SIMPULAN}

Berdasarkan penelitian yang dilakukan, dapat di buat sebuah tabel simpulan (Tabel 1):

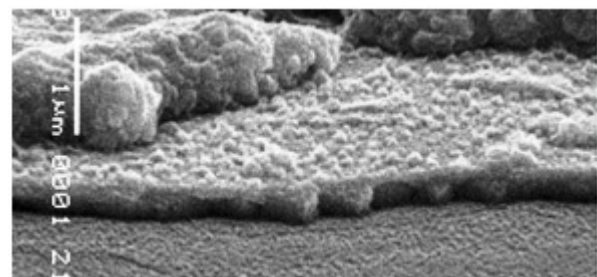

(a)Sampel P

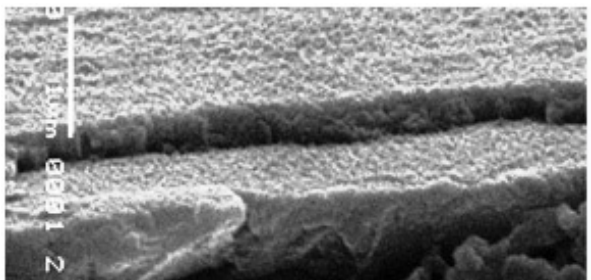

(b)Sampel O

Gambar 4: Hasil foto SEM tampang melintang

1. Hasil karakterisasi XRD menunjukkan untuk mendapatkan deposit magnetite di atas substrat, sampel hasil deposisi harus dipanaskan.

2. Tanpa penambahan surfaktan ukuran kristal yang dihasilkan lebih besar dari pada sampel dengan penambahan surfaktan ethylene glycol. 
TABEL I: Hasil karakterisasi XRD dan SEM

\begin{tabular}{ccccccc}
\hline \hline No Nama ampel & Kuat arus & Ukuran kristal $(\mathrm{nm})$ & Ukuran partikel & Tebal lapisan & Keterangan \\
\hline & & & & & \\
1 & A.1 & $4,03 \mathrm{~mA}$ & - & - & - & tanpa pemanasan \\
2 & A.2 & $4,03 \mathrm{~mA}$ & 185,521 & $73,08 \mathrm{~nm} \mathrm{~s} / \mathrm{d} 380,77 \mathrm{~nm}$ & - & dengan pemanasan \\
3 & B & $4,09 \mathrm{~mA}$ & 32,617 & - & - & dengan pemanasan \\
4 & C & $3,96 \mathrm{~mA}$ & 32,617 & $84,62 \mathrm{~nm} \mathrm{~s} / \mathrm{d} 142,31 \mathrm{~nm}$ & $360,825 \mathrm{~nm}$ & dengan pemanasan \\
5 & D & $230,88 \mu \mathrm{A}$ & 40,768 & $61,54 \mathrm{~nm} \mathrm{~s} / \mathrm{d} 130,77 \mathrm{~nm}$ & $268,041 \mathrm{~nm}$ & dengan pemanasan \\
\hline \hline
\end{tabular}

3. Penambahan surfaktan akan mempengaruhi nilai parameter kisi yang dihasilkan, semakin tinggi konsentrasi surfaktan semakin tinggi parameter kisi yang didapatkan. Konsentrasi surfaktan yang terlalu pekat juga akan bertindak sebagai pengganggu karena ukuran kristal dan jarak antar bidang kristal yang dihasilkan lebih besar sehingga perlu diperhatikan perbandingan konsentrasi surfaktan ethylene glycol terhadap pelarutnya.

4. Perbandingan konsentrasi surfaktan ethylene glycol terhadap pelarutnya mempengaruhi morfologi lapisan tipis, kondisi larutan yang paling optimum untuk membentuk lapisan adalah pada konsentrasi rendah. Pekatnya surfaktan ethylene glycol, menghasilkan hasil deposisi dalam bentuk agregat atau cluster berbentuk butiran bola dari kristal-kristal magnetite.

5. Retakan-retakan yang terjadi pada hasil deposisi, kemungkinan dapat diatasi dengan cara menurunkan suhu pembakaran dan lama waktu tahan pembakaran.
[1] Siyambalapitiya, Chamila S., Growth And Physical Properties of Magnetite Thin Films, (Graduate School Theses and Dissertations. Paper 2705, 2006).

[2] R.F. Butler, Paleomagnetism: Magnetik Domains to Geologic Teranes (Boston: Blackwell Scientific Publications, 1992).

[3] J. Chumming, and L. Xiangqin, J. Solid State Electrochem, 13, 1273-1278 (2009).

[4] B. Gaihre, et al., J. Pharm., 365, 180-189 (2009).
[5] T.Y. Liu, et al., Nano Today, 4, 52-65 (2009).

[6] X. Jia, , et al., Electrochem. Commun., 11, 141-144 (2009).

[7] A.Yulianto, Bijaksana S, Loeksmanto W., Karakterisasi Magnetik dari Pasir Besi Cilacap, Jurnal Himpunan Fisika Indonesia, A5 no. 0527 (2002).

[8] M. Abdullah, Pengantar Nanosains (Bandung, ITB, 2009) 